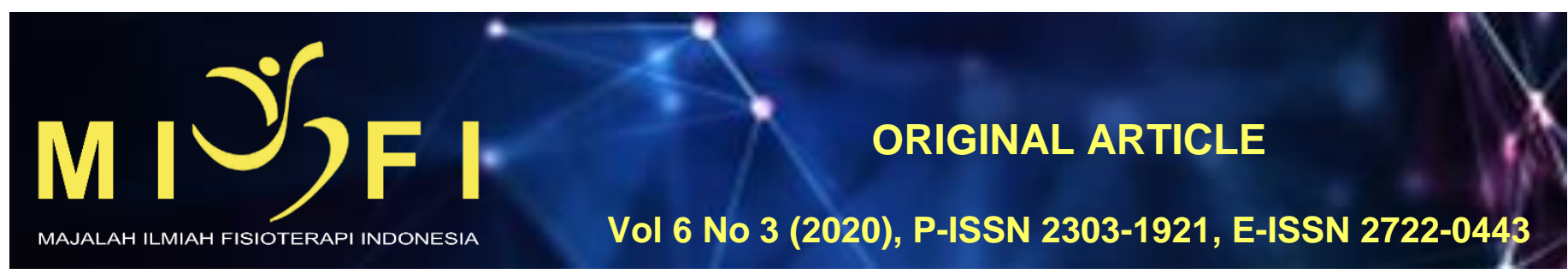

\title{
HUBUNGAN DAYA LEDAK LENGAN DENGAN KEMAMPUAN PUKULAN GYAKU TSUKI DI DOJO KARATE DI DENPASAR
}

\author{
Putu Adhika Satria Utama Wicaksana Aji Amertha ${ }^{1}$, I Made Niko Winaya ${ }^{2}$, Nila Wahyuni ${ }^{3}$, I Made Krisna Dinata ${ }^{4}$ \\ ${ }^{1}$ Program Studi Sarjana Fisioterapi dan Profesi Fisioterapi, Fakultas Kedokteran, Universitas Udayana, Denpasar, Bali \\ ${ }^{2}$ Departemen Fisioterapi, Fakultas Kedokteran, Universitas Udayana, Denpasar, Bali \\ ${ }^{3,4}$ Departemen IImu Faal, Fakultas Kedokteran, Universitas Udayana, Denpasar, Bali \\ adhikaamerthaa@gmail.com
}

\begin{abstract}
ABSTRAK
Karate merupakan beladiri menggunakan tangan kosong yang pertama kali populer di Jepang. Gyaku Tsuki merupakan teknik pukulan efektif yang sangat sering digunakan saat pertandingan kumite. Kondisi fisik karateka berperan penting dalam peningkatan prestasi karateka, daya ledak lengan adalah salah satu komponen dari kondisi fisik yang berperan penting dalam menghasilkan pukulan yang keras dan cepat. Adapun tujuan penelitian adalah untuk mengetahui hubungan antara daya ledak lengan dengan kemampuan pukulan gyaku tsuki di Dojo Karate di Denpasar. Penelitian ini merupakan penelitian observasional yang menggunakan desain cross sectional. Penelitian dilaksanakan pada bulan Mei-Juni 2020 di Dojo Karate di Denpasar dan rumah subjek karena sulitnya mengumpulkan subjek setelah PSBB (pembatasan sosial berskala besar) sehingga peneliti harus mengumpulkan data di Dojo dan rumah subjek. Teknik pengambilan sampel menggunakan teknik purposive sampling, dengan total subjek sebanyak 54 dan berusia1015 tahun. Berdasarkan uji analisis parametrik pearson correlation didapatkan hubungan yang kuat dan signifikan antara daya ledak lengan dengan kemampuan pukulan gyaku tsuki dengan nilai $p=0,000(p<0,05)$ dan nilai korelasi $(R)$ sebesar 0,915 .
\end{abstract}

Kata Kunci: daya ledak lengan, gyaku tsuki, karate

\section{THE CORRELATION BETWEEN ARM EXPLOSIVE POWER AND THE ABILITY TO DO GYAKU TSUKI CHUDAN AT KARATE DOJO IN DENPASAR}

ABSTRACT
Karate is a martial art using bare hands that was first popular in Japan. Gyaku Tsuki is one of the punch techniques that are often used and effective to attack in kumite matches. The physical condition of the karateka is important in increasing their performance, arm explosive power is one of physical condition which affects the execution of gyaku tsuki technique to produce a strong and fast punch. The purpose of this research is to see whether or not there is a correlation between explosive power of the arm and the ability to do gyaku tsuki. This study is an observational study using cross sectional design. This study was conducted on May-June 2020 in Karate Dojo in Denpasar and subject's house because it was hard to gather all the subject after PSBB (pembatasan sosial berskala besar) with the result that the the data was collected some in Dojo and subject's house. Based on pearson correlation parametric analysis test obtained a strong and significant relationship between explosive power of the arm and ability to do gyaku tsuki with $p$ value $=0,000(p<0,05)$ and correlation value $(R)$ of 0,915 .

Key word: arm explosive power, gyaku tsuki, karate

\section{PENDAHULUAN}

Karate merupakan salah satu jenis beladiri yang memiliki aliran keras yang menggunakan berbagai teknik fisik seperti tangkisan, pukulan, elakan, dan tendangan menggunakan kuda-kuda. Karate juga merupakan cabang olahraga yang dijadikan olahraga prestasi. Dinamisnya perkembangan dan semakin luasnya penyebaran fenomena olahraga puluhan tahun belakangan menggiring olahraga menjadi lembaga yang terorganisir dengan baik. ${ }^{1}$

Karate-do merupakan jenis beladiri yang awalnya populer di Jepang. Karate-do tersusun dari 3 kata yaitu kara yang memiliki arti kosong ataupun hampa, te yang memiliki arti tangan dan do yang memiliki arti jalur atau jalan menuju suatu tujuan/pedoman. Sehingga karate-do merupakan sebuah aliran khusus dengan tujuan melindungi diri menggunakan anggota tubuh dengan menjalani latihan yang baik dan alami, yang telah didasari serta memiliki tujuan sesuai nilai dari filasafat Timur dengan menggunakan berbagai teknik fisik yaitu tangkisan, pukulan, elakan, dan tendangan menggunakan kuda-kuda yang baik. ${ }^{2,3}$

Salah satu jenis cabang olahraga yang dipertandingkan dalam olahraga karate adalah kumite. Kumite memiliki arti pertemuan tangan dan biasa juga disebut sebagai pertarungan bebas. Pada pertandingan ini karateka memerlukan serangan yang kuat dan akurat serta cepat meuju ke daerah sasaran. Dalam pertandingan karate, penggunaan teknik serangan ekstremitas atas lebih tinggi dibandingkan dengan penggunaan serangan ekstremitas bawah baik selama simulasi maupun pertandingan resmi. Pukulan gyaku tsuki merupakan teknik serangan ekstremitas atas yang paling dominan dilakukan oleh seorang karateka dalam kumite dibandingkan teknik pukulan lain. ${ }^{4,5}$ 
Pukulan gyaku tsuki merupakan teknik pukulan yang paling efektif dalam pengeksekusiannya, hal ini disebabkan oleh gerakan pukulan gyaku tsuki ini tergolong cukup mudah dan merupakan gerakan dasar yang dipelajari karateka. Gyaku tsuki adalah teknik pukulan dalam bela diri karate yang mengarah lurus ke depan dengan keras dan cepat, menggunakan tenaga secara maksimal, pukulan gyaku tsuki menggunakan tangan memukul yang berlawanan dengan kaki kuda-kuda yang menopang di depan sehingga tangan dan kaki yang memukul ada pada sisi berlawanan. Dalam pertandingan kumite pukulan gyaku tsuki dilakukan dengan kecepatan maksimal sehingga karateka dapat kembali ke posisi awal (posisi bertahan) untuk mengantisipasi serangan lawan dengan menurunkan lengan atas dan melakukan gerakan fleksi elbow secepat mungkin setelah akhir pukulan gyaku tsuki baik saat serangan mengenai target maupun tidak sehingga karatekadapat bersiaga apabila adanya serangan balasan. ${ }^{6}$

Hal yang perlu diperhatikan dalam peningkatan prestasi karate adalah kondisi fisik, taktik bermain, teknik, serta kesiapan mental. Kondisi fisik merupakan pondasi dasar dalam peningkatan kemampuan yang juga dimiliki oleh setiap atlet dalam bidang olahraga lainnya apabila meraih prestasi yang tinggi. Kesempurnaan penguasaan teknik dasar secara menyeluruh serta gerakan eksplosif akan sangat menentukan kemampuan seseorang dalam menampilkan kecakapan pada olahraga bela diri karate. Secara garis besar terdapat dua jenis kondisi fisik. Kekuatan, fleksibilitas dan stabilitas merupakan parameter fisiologis yang terkait dengan kondisi fisik yang berhubungan dengan kesehatan yang dapat disebut health related fitness. Skill related fitness merupakan komponen kondisi fisik yang berhubungan dengan kinerja motorik yang tediri dari daya ledak (power), keseimbangan (balance), kelincahan (agility), koordinasi (coordination), waktu reaksi (reaction time) dan kecepatan (speed). Selama latihan karate, karateka membutuhkan kemampuan aerobic dan anaerobic yang didefinisikan sebagai gerakan eksplosif, intermitten dan cepat yang dilakukan oleh bagian tubuh atas maupun bagian tubuh bawah karateka. Selama kumite, karateka melakukan gerakan highintensity yang pendek dan dipisahkan oleh gerakan low-to-moderate-intensity dengan periode yang panjang. Sehingga serangan yang kuat dan cepat saat pertandingan kumite penting karena adanya perubahan situasi yang besar. Daya ledak lengan merupakan komponen kondisi fisik skill related fitness yang dibutuhkan ketika mengeksekusi serangan alat gerak atas sehingga menghasilkan serangan dengan intensitas tinggi yang kuat dan cepat dalam pertandingan kumite. ${ }^{7,8,9}$

Berdasarkan pemaparan diatas, peneliti menilai pentingnya melakukan penelitian mengenai hubungan daya ledak lengan dengan kemampuan pukulan gyaku tsuki di dojo karate di Denpasar. Penelitian ini dilaksanakan dengan tujuan agar mengetahui gambaran umum dari daya ledak lengan dan kemampuan pukulan gyaku tsuki dan membuktikan hubungan daya ledak lengan terhadap kemampuan pukulan gyaku tsuki di Dojo Karate di Denpasar.

\section{METODE}

Penelitian ini merupakan penelitian jenis observasional dengan menggunakan desain cross sectional (potong lintang). Penelitian ini telah lulus uji kelaikan etik dari Komisi Etik Penelitian (KEP) Fakultas Kedokeran Universitas Udayana/ Rumah Sakit Umum Pusat Sanglah Denpasar dengan nomor 1225/UN14.2.2.VII.14/LT/2020. Subjek penelitian ini adalah 54 karateka di dojo di Denpasar dengan teknik pengambilan subjek secara purposive sampling yang memenuhi kriteria inklusi dan eksklusi.

Kriteria inklusi meliputi: subjek dengan jenis kelamin laki-laki dan perempuan, berusia 10-15 tahun, kehadiran dalam latihan rutin selama dua bulan terakhir minimal $75 \%$ sebelum terjadinya pandemi, bersedia secara sukarela sebagai subjek penelitian dari awal sampai akhir penelitian dengan menandatangani informed consent yang disediakan peneliti, sudah dalam tingkatan sabuk kuning, keadaan umum sehat, vital sign dalam batas normal dengan melakukan pemeriksaan fisioterapi. Kriteria eksklusi meliputi: memiliki riwayat fraktur atau cedera muskuloskeletal yang pada punggung dan ekstremitas atas. Kriteria drop out pada penelitian ini adalah subjek tidak mengindahkan intruksi yang diberikan dan subjek mengundurkan diri.

Penelitian ini mengukur 2 variabel pada seluruh subjek, satu variabel terikat yaitu daya ledal lengan dan satu variabel bebas yaitu kemampuan pukulan gyaku tsuki. Daya ledak lengan akan diukur menggunakan Medicine Ball Throw Test. Kemampuan pukulan gyaku tsuki diukur menggunakan Tes Pukulan Gyaku Tsuki. Karena penelitian ini dilakukan setelah PSBB menyebabkan sulitnya mengumpulkan sampel di dojo karate, sehingga peneliti melakukan penelitian di 3 dojo karate di Denpasar dan rumah sampel yang sudah mengizinkan peneliti untuk mengambil data sesuai protokol.

\section{HASIL PENELITIAN Karakteristik Subjek Penelitian}

Tabel 1. Karakteristik Subjek Penelitian

\begin{tabular}{ccc}
\hline Karakteristik & Frekuensi (n) & Persentase (\%) \\
\hline Usia & & \\
10 tahun & 15 & 27,8 \\
11 tahun & 5 & 9,3 \\
12 tahun & 14 & 25,9 \\
13 tahun & 10 & 18,5 \\
14 tahun & 6 & 11,1 \\
15 tahun & 4 & 7,4 \\
\hline Jenis Kelamin & & \\
Laki-laki & 35 & 64,8 \\
Perempuan & 19 & 35,2 \\
\hline
\end{tabular}


Berdasarkan tabel di atas dapat dilihat usia subjek didominasi oleh karateka berusia 10 tahun. Jenis kelamin subjek penelitian ini didominasi oleh laki-laki.

Tabel 2. Karakteristik subjek penelitian

\begin{tabular}{ccccc} 
Kategori & Nilai Min. & Nilai Max. & Rata-rata & Std. Deviation \\
\hline Daya Ledak Lengan & 168 & 546 & 304,35 & 80,557 \\
Pukulan Gyaku Tsuki & 18 & 40 & 28,04 & 5,128 \\
\hline
\end{tabular}

Berdasarkan tabel 2 dapat diketahui sebaran data dari kedua variabel. Pertama, pada variabel daya ledak lengan, medicine ball throw test digunakan sebagai tes untuk mengukur daya ledak. Sebagian besar atau 34 subjek berada di bawah rata-rata yaitu 304,35. Nilai daya ledak lengan pada tabel di atas akan memiliki pengaruh pada hasil kemampuan pukulan gyaku tsuki pada subjek. Kedua, pada kemampuan gyaku tsuki sebagian besar atau 31 subjek berada di bawah rata-rata yaitu 28,04 .

Tabel 3. Uji Pearson Correlation

\begin{tabular}{ccc}
\hline Korelasi Variabel & R & P value \\
\hline Daya ledak lengan dengan kemampuan pukulan gyaku tsuki & 0,915 & 0,000 \\
\hline
\end{tabular}

Analisa yang digunakan dengan tujuan mengetahui hubungan antara daya ledak lengan dengan kemampuan pukulan gyaku tsuki adalah dengan uji pearson correlation. Pada Tabel 3 ditunjukkan bahwa terdapat hubungan yang signifikan antara daya ledak lengan dengan kemampuan pukulan gyaku tsuki dimana nilai $p<0,05$. Nilai korelasi (R) antara variabel daya ledak lengan dengan kemampuan pukulan gyaku tsuki diperoleh sebesar 0,915 yang berarti ada hubungan searah positif dengan hubungat yang kuat antara daya ledak lengan dengan kemampuan pukulan gyaku tsuki.

\section{DISKUSI}

Hasil penelitian menunjukkan bahwa peserta paling banyak merupakan karateka laki-laki sebanyak 35 orang, diikuti dengan karateka perempuan sebanyak 19 orang. Sehingga hasil pada penelitian ini didominasi oleh sampel dengan jenis kelamin laki-laki yang dimana tekanan kontraksi maksimum yang dihasilkan oleh laki-laki lebih tinggi jika dibandingkan dengan tekanan kontraksi maksimum perempuan dengan perbandingan $4 \mathrm{~kg} / \mathrm{cm}$ untuk laki-laki sedangkan perempuan $3 \mathrm{~kg} / \mathrm{cm}$, selain itu perbedaan dari kekuatan otot terjadi secara signifikan seiring dengan pertambahan usia, dimana kekuatan otot laki-laki jauh lebih kuat jika dibandingkan dengan perempuan. ${ }^{10,11} \mathrm{Hal}$ ini didukung oleh penelitian mengenai jenis kelamin dan jenis serat otot dalam serat otot tunggal manusia menemukan bahwa nilai specific force pada laki-laki lebih tinggi dibanding perempuan dimana untuk serat otot tipe Ilx perempuan memiliki kekuatan otot lebih rendah $60,2 \%$ dibanding laki-laki dengan nilai $\mathrm{P}<0,05$, namun tidak ada perbedaan yang spesifik pada tipe otot lainnya $(P>0,05) .{ }^{12}$

Dilihat dari distribusi data daya ledak lengan dapat dilihat bahwa sampel dengan kemampuan daya ledak didominasi oleh karateka dengan nilai berkisar $263-367 \mathrm{~cm}$ yaitu sebanyak 24 orang. Hal kemungkinan terjadi melihat karakteristik subjek yang sebagian besar didominasi oleh usia 10, 12 dan 13 tahun dimana usia dapat mempengaruhi daya ledak seseorang sehingga mendapatkan hasil yang didominasi oleh sampel dengan nilai berkisar 263-367 dimana hal ini dikategorikan sebagai kurang. Daya ledak (kekuatan eksplosif, kekuatan otot) merupakan kemampuan untuk melakukan suatu kegiatan secara cepat dan spontan dengan menggunakan segenap kekuatan (strength) dalam kurun waktu yang singkat. Daya ledak lengan sangat besar pengaruhnya dalam gerakan olahraga yang melibatkan gerakan kuat serta cepat. ${ }^{13,14}$

Ditinjau dari kemampuan pulukan gyaku tsuki peserta penelitian didominasi oleh karateka yang mencapai 2635 kali pukulan dalam 15 detik sebanyak 32 (59,1\%) peserta. Dibutuhkan persiapan cermat dalam melakukan latihan dengan gerakan kompleks. Kondisi fisik berbarengan dengan keadaan mental yang baik akan mendukung persiapan dalam peningkatan keterampilan motorik sehingga dapat menghasilkan gerakan yang baik. Latihan dengan tujuan meningkatkan daya ledak lengan mampu meningkatkan kemampuan pukulan gyaku tsuki. ${ }^{15,16}$ Kemampuan pukulan gyaku tsuki tidak terlepas dari kekuatan pukulan dalam mengeksekusi gerakan. Kualitas pukulan olahraga beladiri dipengaruhi juga oleh kekuatan dan daya ledak atlet tersebut. ${ }^{17}$

Berdasarkan hasil pengujian data pearson correlation dengan nilai asymptotic significance (2-sided) pada jumlah data sebanyak 54 sampel, ditemukan nilai p 0,000 yang menunjukkan nilai yang kurang dari nilai standar 0,05 $(p<0,05)$. Pada nilai tersebut ini menunjukkan terdapat hubungan daya ledak lengan dengan kemampuan pukulan gyaku tsuki pada karateka di dojo di Denpasar. Kuat hubungan daya ledak lengan dengan kemampuan pukulan gyaku tsuki dengan nilai r sebesar 0,915 dengan interpretasi kuat $(0,8-1,00)$ yang memiliki hubungan yang searah dan positif karena nilai $r$ positif. Hal tersebut memiliki arti bahwa semakin tinggi nilai daya ledak lengan maka semain tinggi kemampuan pukulan gyaku tsuki nya.

Hal ini serupa dengan penelitian Pratama pada tahun 2019 yang meneliti hubungan daya ledak otot lengan dan bahu dengan terhadap kecepatan pukulan gyaku-tsuki atlet karate-do Dojo Gaya Baru Kota Meduri. Tes daya ledak lengan yang digunakan pada penelitian tersebut adalah medicine ball throw test. Hasil penelitian tersebut menunjukkan nilai $r$ hitung $=0.984$ lebih besar dari $r$ tabel $=0.878$ yang menunjukkan terdapat hubungan antara daya ledak otot lengan dan bahu terhadap kecepatan pukulan gyaku-tsuki. ${ }^{18}$

Dyson et al pada tahun 2007 melakukan penelitian tentang otot-otot yang terlibat dalam pukulan tinju untuk memahami peran otot individu utama dalam pukulan. Ditemukan bahwa gastrocnemius adalah otot pertama yang diaktifkan ketika pukulan karena tindakan menggerakkan tubuh maju dengan gerakan plantar fleksi. Rektus femoris dan biceps femoris diaktifkan di samping untuk memperpanjang lutut dan pinggul. Diikuti oleh trapezius, deltoid dan biceps 
brachii yang melakukan gerakan fleksi dari siku, setelah itu terjadi gerakan ekstensi siku yang dilakukan oleh triceps brachii dan fleksor karpi radialis di lengan bawah untuk eksekusi pukulan. Kelompok otot yang terlibat ketika gerakan pronasi pergelangan tangan dan lengan ketika melakukan gyaku tsuki normal menghasilkan momen yang lebih tinggi sehingga mengarah ke munculnya pukulan yang lebih kuat. Hal ini sesuai dengan kecepatan yang lebih tinggi dibandingkan dengan pukulan gyaku tsuki tanpa rotasi wrist. Untuk meningkatkan kecepatan pukulan apapun, memutar panggul mentransfer kenaikan dalam kecepatan sudut ke lengan. Gyaku tsuki yang dilakukan dimulai dari dekat pinggang menghasilkan lebih banyak kecepatan linear pergelangan tangan dibanding dengan memulai pukulan di tengah jalan. Dan juga, bila lengan yang berlawanan lebih cepat ditarik, maka pukulan yang dihasilkan juga akan lebih cepat. ${ }^{19,20}$

Peningkatan pada daya ledak lengan memiliki pengaruh positif terdahap kemampuan pukulan gyaku tsuki karateka, pada penelitian yang digarap oleh Manullang pada tahun 2014 mengenai pengaruh metode latihan dan power lengan terhadap kecepatan pukulan gyaku tsuki chudan pada cabang olahraga karate dojo khsus Unimed, dimana ditemukan hasil kecepatan pukulan gyak tsuki chudan dengan pemberian latihan dumble press dan medicine-ball wall throw menghasilkan pengaruh yang berbeda ditiap latihannya, daya ledak lengan dengan nilai yang tinggi dan daya ledak lengan dengan nilai yang rendah mempengaruhi performa kecepatan dari pukulan gyaku tsuki, terdapat perbedaan hubungan antara jenis latihan dan daya ledak lengan terhadap performa dari kecepatan pukulan gyaku tsuki. Pada penelitian tersebut, disebutkan bahwa terdapat peningkatan kemampuan pukulan gyaku tsuki chudan pada pretest dan juga post-test dimana hasil latihan dengan peningkatan daya ledak lengan yang lebih tinggi menghasilkan peningkatan kecepatan pukulan gyaku tsuki chudan yang lebih tinggi. ${ }^{15}$

Gerakan konsentrik dari otot mampu menghasilkan lebih sedikit daya ledak jika dibandingkan dengan gerakan eksentrik. Namun, penggunaan aksi konsentrik dan eksentrik yang bersamaan dapat meningkatkan daya ledak sehingga didapatkannya keuntungan yang berasal dari properti elastis pada otot ketika siklus stretch-shortening. Stretch-shortening cycle atau siklus stretch-shortening dimulai ketika gerakan berlawanan secara cepat kemudian mengakibatkan terjadinya peregangan dari target otot melalui aksi eksentrik. Unsur bagian elastis yang dibentuk oleh lapisan jaringan otot yang dikelilingi oleh jaringan ikat yang menyebabkan otot dapat ter-regang. Ketika otot ter-regang, mekanoreseptor spesifik pada otot yang disebut muscle spindle juga ter-regang dan menghasilkan umpan balik ke pusat sistem saraf. Umpan balik ini menyebabkan pensinyalan langsung dari serat otot untuk berkontraksi untuk mencegah potensi kerusakan jaringan karena peregangan yang berlebihan. Saat disinkronisasikan dengan aksi otot konsentrik, reflex peregangan ini menghasilkan peningkatan akselerasi dari tubuh atau anggota tubuh yang terlibat dalam gerakan. Hal ini menyerupai pola gerakan dari gyaku tsuki, dimana sebelum melakukan pukulan karateka akan mengambil posisi menarik tangan yang akan digunakan untuk melakukan pukulan mendekati tubuh lalu melontarkan pukulan dengan kekuatan penuh. ${ }^{21}$

\section{SIMPULAN}

Berdasarkan hasil penelitian yang telah dilakukan sehingga dapat ditarik kesimpulan bahwa adanya hubungan antara daya ledak lengan dengan kemampuan pukulan gyaku tsuki di dojo karate di Denpasar.

\section{DAFTAR PUSTAKA}

1. Muda, I. 2018. Hubungan Daya Ledak Otot Lengan Kecepatan Reaksi Tangan Dan Ketepatan Dengan Kemampuan Pukulan Gyaku Tzuki Cabang Olahraga Karate BKMF Karate FIK UNM. Makasar: Universitas Negeri Makasar: S.n

2. Wahid, Abdul. 2007. Shotokan Sebuah Tinjauan Alternatif Terhadap Aliran Karate-Do Terbesar di Dunia. PT Raja Grafindo Persada, Jakarta.

3. Santos, M. H. D., 2016. Pengaruh Metode Latihan Beban Dan Kecepatan Reaksi Tangan Terhadap Kecepatan Pukulan Kizami-Gyaku Tsuki Pada Karateka Inkanas Unm. Makasar: Universitas Negeri Makasar: S.n

4. Monalisa, 2014. Hubungan Reaksi Tangan Dan Power Lengan Dengan Kemampuan Pukulan Gyakusuki Cabang Olahraga. Bandar Lampung: Universitas Lampung: S.n

5. Franchini, E. Nakamura, F.Y. Loturco, I. et al., 2015. Performance Analysis In Karate. Omics Group E-Book

6. Quinzi, F. Sbricolli, P. Felici, F. 2018. Higher Torque And Muscle Fibre Conduction Velocity Of The Biceps Brachii In Karate Practitioners During Isokinetic Contraction. Journal Of Electromyography And Kinesiology.

7. Micheo, M. Baerga, L. Miranda, G., 2012. Basic Principles Regarding Strength, Flexibility And Stability Exercises. American Academy Of Physical Medicine And Rehabilitation, Pp. 805-811.

8. Jeng, S.C. Chang, C.W. Liu, W.Y. et al, 2016. Exercises Training On Skill Related Physical Fitness In Adolescents With Intellectual Disability: A Systematic Review And Meta-Analysis. Disability And Health, Pp. 1-9.

9. Chaabène, H. Franchini, E. Sterkowicz, S. 2015. Physiological Responses To Karate Specific Activities. Science And Sports, P. 9.

10.Munawaroh, S. 2016. Pengaruh Dynamic Sterching dan Depth Jump terhadap Peningkatan Power Pemain Voli. Yogyakarta: UNISA

11.Guna, I. S., 2017. Pengaruh Theraband Terhadap Peningkatan Daya Ledak Tungkai Di Klub Futsal Fisio $8 b$ Unisa Yogyakarta. Yogyakarta: Universitas Aisyiyah.

12.Jeon,Y. Choi, J. Kim, H. J. et al. 2019. Sex- and Fiber-Typle-Related Contractile Properties in Human Single Muscle Fiber. Journal of Exercise and Rehabilitation. 15(4): 547-545

13.Santos, Eduardo J. A. M. Janeira, Manuel A. A. S. 2008. Effects of Complex Training on Explosive Strength in Adolescent Male Basketball Players. Journal of Strength and Conditioning Research. 22(3);903-909

14.Anisah, F., 2009. Sumbangan Daya Ledak Otot Lengan Bahu, Kekuatan Otot Lengan Bahu Dan Daya Ledak Otot Tungkai Terhadap Hasil Jumping Service Dalam Permainan Bola Voli Pada Pemain Klub Ivokas Kabupaten Semarang Tahun 2009. Semarang: Universitas Negeri Semarang: S.n 
15.Manullang, G. J. Soegiyanto, Sulaiman. 2014. Pengaruh Metode Latihan Dan Power Lengan Terhadap Kecepatan Pukulan Gyaku Tsuki Chudan Pada Cabang Olahraga Karate Dojo Khusus Unimed. Journal Of Physical Education And Sports. 3(2)

16.Saputra, S. A. Imanudin, I. (2017). Pengaruh Latihan Karet dan Latihan Beban Terhadap Peningkatan Power Lengan dan Kecepatan Pukulan Gyaku Zuki Chudan. Jurnal Terapan Ilmu Keolahragaan Special Issue 01 Seminar Nasional IImu Keolahragaan. 15 (2): 36 - 43.

17.Loturco, I. Nakamura, F. Y. Artioli G. G. 2015. Strength And Power Qualities Are Highly Associated With Punching Impact In Elite Amateur Boxer. Journal Of Strength And Conditioning Research, 30(1), Pp. 109-115.

18.Pratama, Y. Zainur. Vai, A. 2019. Hubungan Daya Ledak Otot Lengan dan Bahu Terhadap Kecepatan Pukulan Gyaku-Tsuki Atlet Karate-do Dojo Gaya Baru Kota Duri. JOM FKIP. Vol. 6 Ed. 2.

19.Dyson, R. Smith, M. Martin, C. et al. 2007. Muscular Recruitment During Rear Hand Punches Delivered at Maximal Force and Speed by Amateur Boxers. ISBS-Conference Proceedings Archive

20.Venkatraman, J. Nasiriavanaki, M. Biomechanics of Kumite Style Gyaku Tsuki in Karate. Biomedical Journal of Scientific and Technical Research. 14(3): 10656-10662

21.Kraemer, W. J. Looney, D. P. 2012. Underlying Mechanism and Physiology of Muscular Power. Strength and Conditioning Journal. 34(6) 13-19 